Sains Malaysiana 49(12)(2020): 3007-3015

http://dx.doi.org/10.17576/jsm-2020-4912-12

\title{
Electrochemical Properties of Natural Sensitizer from Garcinia mangostana and Archidendron pauciflorum Pericarps for Dye-Sensitized Solar Cell (DSSC) Application
}

(Sifat Elektrokimia Pemekaan Semula Jadi daripada Perikarpa Garcinia mangostana dan Archidendron pauciflorum untuk Penggunaan Sel Suria Peka Pewarna (DSSC))

Mashasriyah Ismail, Norasikin Ahmad Ludin*, Norul Hisham Hamid, Mahmoud A.M. Al-Alwani,

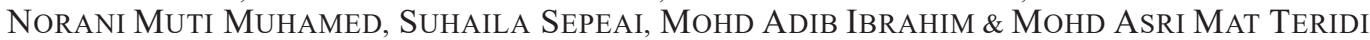

\begin{abstract}
Dye-sensitized solar cells (DSSC) create imitation photosynthesis by using chemical reactions to produce electricity from sunlight. DSSC has been pursued in numerous studies due to its capability to achieve efficiencies of up to $15 \%$ with artificial photosensitizer in diffuse light. However, artificial photosensitizers present a limitation because of the complex processing of metal compound. Therefore, various types of sensitizers were developed and synthesized to surpass the artificial sensitizer performances such as natural sensitizers from bio-based materials including plants, due to simple processing techniques and low environmental impact. Thus, this study examines the potential and properties of natural sensitizers from the waste of bio-based materials from Garcinia mangostana (mangosteen fruit) and Archidendron pauciflorum (jering fruit). Both fruits pericarps have dark color pigments as dark purple and dark brown, respectively, which promise a good absorption and has potential to be used as sensitizer for DSSC. Each pericarps dye extracted using cold extraction method in methanol solvent. Electrochemical properties and photovoltaic properties of the natural photosensitizers were studied. The highest peaks of photoluminescence spectra of mangosteen and jering sensitizers were at 490 and $670 \mathrm{~nm}$, respectively, due to their different types of dye pigment extracted. We also obtained the absorption spectra for both mangosteen and jering sensitizers at 380-500 and 400-600 $\mathrm{nm}$, respectively, in blue shift behavior. The redox reaction was also studied using cyclic voltammetry and identify their energy levels. The DSSC device with mangosteen sensitizer achieved an efficiency of $0.38 \%$ with $35.43 \%$ (IPCE at $337 \mathrm{~nm}$ ) and $37.75 \Omega(R s)$, whereas that with jering sensitizer has efficiency of $0.07 \%$ with 25.31\% (IPCE at $337 \mathrm{~nm}$ ) and $490.70 \Omega$ (Rs). Performance studies for both photosensitizers were weak due to their HOMO-LUMO levels, but the results show that both natural dyes can be potentially applied as photosensitizer in DSSC.
\end{abstract}

Keywords: Absorption; DSSC; efficiency; natural dye; photosensitizer

ABSTRAK

Sel suria peka pewarna (DSSC) membuat fotosintesis tiruan dengan menggunakan tindak balas kimia untuk menghasilkan elektrik daripada cahaya matahari. Peranti DSSC telah digunakan dalam banyak kajian kerana kemampuannya untuk mencapai kecekapan hingga 15\% dengan pemeka warna buatan dalam cahaya yang resap. Walau bagaimanapun, pemeka warna buatan mempunyai batasan kerana mengandungi sebatian logam yang kompleks. Oleh itu, pelbagai jenis pemeka warna dikaji dan disintesis untuk mengatasi prestasi pemekaan buatan seperti pemeka semula jadi daripada bahan berasaskan bio termasuk tanaman, kerana teknik penghasilan pemeka yang mudah dan kesan persekitaran yang rendah. Oleh itu, kajian ini mengkaji potensi dan sifat pemekaan semula jadi daripada bahan buangan berasaskan bio daripada Garcinia mangostana (buah manggis) dan Archidendron pauciflorum (buah jering). Kedua-dua buah masing-masing mempunyai kulit perikarpa yang berwarna gelap iaitu ungu gelap dan coklat gelap yang boleh membantu mendapatkan penyerapan cahaya yang baik dan berkebolehan dijadikan pemeka untuk peranti DSSC. Pewarna diekstrak menggunakan kaedah pengekstrakan sejuk di dalam larutan metanol. Sifat elektrokimia dan fotovoltaik pemeka warna semula jadi ini dianalisis dalam kajian ini. Puncak tertinggi spektrum fotoluminesen pemeka manggis dan jering adalah masing-masing pada 490 dan $670 \mathrm{~nm}$, kerana pelbagai jenis pigmen pewarna yang diekstrak. Kami juga dapat memperoleh spektrum penyerapan untuk kedua-dua pemeka manggis dan jering pada masingmasing 380-500 dan 400-600 nm, dalam tingkah laku anjakan biru. Tindak balas redoks juga dikaji menggunakan 
voltametri berkitar dan mengenal pasti tahap tenaga pemeka tersebut. Peranti DSSC dengan pemeka warna manggis mencapai kecekapan peranti 0.38\% dengan 35.43\% (IPCE pada $337 \mathrm{~nm}$ ) dan $37.75 \Omega$ (Rs), sedangkan pemeka warna jering mempunyai kecekapan peranti $0.07 \%$ dengan 25.31\% (IPCE at $337 \mathrm{~nm}$ ) dan $490.70 \Omega$ (Rs). Kajian prestasi peranti untuk kedua-dua pemeka warna tersebut lemah kerana paras HOMO-LUMO pewarna, tetapi hasil kajian menunjukkan bahawa kedua-dua pewarna semula jadi berpotensi digunakan sebagai pemeka cahaya dalam DSSC.

Kata kunci: DSSC; kecekapan; pemeka warna buatan; penyerapan; pewarna semula jadi

\section{INTRODUCTION}

Solar energy is a renewable energy that had been pursued in decades either in commercial or research field. Thus, new generations of devices were created for good performances. The DSSC device is a third-generation photovoltaic device which consists of photoelectrode, counter electrode (CE), sensitizer and electrolyte, and each of these components plays an important role in device mechanisms (Zulkifili et al. 2015).

A sensitizer helps in harvesting sunlight and produces photo-excited electrons (Shahid et al. 2013). Several properties of sensitizer are needed to obtain an efficient DSSC with strong anchoring groups, such as carboxyl and hydroxyl, a potent absorption in the visible region of 400 to $700 \mathrm{~nm}$ and into the semiconductor surface and high extinction coefficient (Ye et al. 2014). Energy levels are crucial, and a sensitizer requires a competent electron injection with a more positive lowest unoccupied molecular orbital (LUMO) than the conduction band (CB) of the semiconductor and more negative highest occupied molecular orbital (HOMO) than the electrolyte potential (Safie et al. 2017a). O'regan and Grätzel (1991) successfully developed a DSSC with low cost and high efficiency of $12 \%$ in diffuse light by using colloidal $\mathrm{TiO}_{2}$ films and newly developed ruthenium (Ru(II)) photosensitizers. Ru (II) sensitizers can exhibit high efficiency because of its wide absorption range below $550 \mathrm{~nm}$ in visible light range and metal component inside its chemical bonding. However, due to this condition, $\mathrm{Ru}$ (II) sensitizer exhibits high toxicity and entails high cost. Researchers prepared different types of sensitizers, including black dye, coumarin, and porphyrins. Other approaches use natural products as sensitizer.

Natural products can be obtained from trees, leaves, flowers, and fruits. Most researchers use natural products consisting of wastes from human usage, including dead tree barks, fruit seeds, fruit pericarps, and fallen leaves or flowers, thereby helping to reduce produced waste (Attanayake et al. 2013). Natural products were also selected due to their organic substances, readily available source and low cost. Natural products also consist of natural carboxyl and hydroxyl groups. Towards 2017,
Sathyajothia et al. (2017) conducted the latest study on natural products by using henna and beetroot dye extracts as DSSC sensitizers and obtained efficiencies of 1.08 and $1.3 \%$, respectively. A. jiringa, also known as dogfruit or jering in Malaysia, is widely used in Asia regions as herbal medicines to cure minor diseases, such as fever, diarrhoea, headaches, stomachache and coughs and is also utilised as traditional fitness supplements. In the use of jering as herbal medicine, only the inside seeds in pods and leaves are utilized, and the external pod, known as pericarp, is discarded due to the absence of nutrients in this part, used as dye for silk and timber wood crafting or burned as firewood (Bunawan et al. 2013). Other natural products that we used in this study included pericarps from Garcinia mangostana, which is locally known as mangosteen. Mangosteen can easily be found in the South Asian region. Locals eat the sweet edible part of the fruit and throw away its outside pericarps. However, other researchers also use mangosteen pericarp for studies on cancer and Alzheimer treatment (Jung et al. 2006).

In DSSC research field, mangosteen pericarps dye had been known to have high efficiency comparing with other natural dye where Maiaugree et al. (2015) study mangosteen pericarps in acetone solvent and obtained efficiency of $1.99 \%$ and Tontapha et al. (2017) studied the mangosteen pericarps in ethanol solvent obtained efficiency of $0.54 \%$. Both studies were observed with surface area of $0.25 \mathrm{~cm}^{2}$. However, jering pericarps has not been studied in DSSC research field. Therefore, in this study, the pericarps of both fruits are extracted with methanol solvent to obtain all target components for anchoring into $\mathrm{TiO}_{2}$ film surfaces. In this study, we utilized two different types of waste from natural products for dye extractions and studied their characteristics to determine their compatibility for DSSC application.

\section{Methods}

MATERIAL

Pericarps of mangosteen and jering, 99.8\% methanol as solvent, fluorine tin oxide (FTO) glass, titanium oxide paste $\left(\mathrm{TiO}_{2}\right)$, platinum $(\mathrm{Pt})$ paste, and iodine electrolyte were used in this study. 


\section{NATURAL DYE PREPARATIONS}

Jering and mangosteen pericarps were obtained from the waste residue of eaten fruits. All pericarps were dried inside a $45^{\circ} \mathrm{C}$ oven for $48 \mathrm{~h}$ and then cut into small pieces for easy crushing into powder by using a blender. After being pulverised, pericarps of the mangosteen and jering were immersed inside the methanol solvent at a ratio of 1:10 for $24 \mathrm{~h}$ (Al-Alwani et al. 2017). This method is known as cold extraction. After $24 \mathrm{~h}$, extracts were filtered with a filter paper to obtain dye extracts and to separate the powder residue. The extraction method was repeated twice at durations of 3 days to fully extract the pigment from the pericarp powder. After the extraction was completed, the extract was concentrated to suitable transparency for DSSC application using a rotary evaporator. Then, the extracts were stored inside a refrigerator until further use in DSSC fabrication.

\section{FULL DSSC DEVICE FABRICATION}

In this study, we used FTO glasses as substrate for both photoanode and $\mathrm{CE}$ at different resistivities of 15 and $8 \Omega$ / sq, respectively. The substrate was cut using a diamond cutter into dimensions of $3 \times 2 \mathrm{~cm}$. The photoanode consists of two different layers of $\mathrm{TiO}_{2}$ deposited by using doctor-blade method at the active area of $1 \mathrm{~cm}^{2}$. The first layer helps absorb the light, followed by the second layer on top annealed to the first layer helping to fully scatter the light inside the layers. Both layers were annealed at a temperature of $450{ }^{\circ} \mathrm{C}$ for $30 \mathrm{~min}$. The photoanode substrate was then immersed inside the selected dye extract for $24 \mathrm{~h}$ after heating at $100{ }^{\circ} \mathrm{C}$ in a furnace. Platinum was deposited into a substrate for $\mathrm{CE}$ by using the same method of doctor-blade method and annealed at the same settings of $450{ }^{\circ} \mathrm{C}$ for $30 \mathrm{~min}$. Both dyeimmersed photoanode and $\mathrm{CE}$ were sandwiched together with surlyn adhesion by using a heat press machine. Then, the electrolyte was inserted inside the sandwiched device and sealed with a polymer glue.

\section{CHARACTERIZATIONS}

Electrochemical properties of the sensitizer were characterised using Fourier transform infrared (FT-IR)near-infrared (NIR) spectroscopy, Ultraviolet/Visible spectrometer (UV-vis), photoluminescence spectroscopy (PL) and cyclic voltammetry (CV). Chemical compound inside the sensitizer was studied using FT-IR spectra measured using Perkin Elmer Spectrum 400 FTIR/FT-NIR and Spotlight 400 imaging systems at wavenumber 4000 to $650 \mathrm{~cm}^{-1}$ (Kushwaha et al. 2013; Mariey et al. 2001). Absorption spectral range for selected sensitizer was studied using Perkin Elmer UV-vis Spectrometer Lambda 35 . The absorption spectral wavelength was measured from 400 to $700 \mathrm{~nm}$. PL was measured using FLS920
Edinburgh Instrument with excitation value of $400 \mathrm{~nm}$. By using PL spectral graph, we obtained energy gap $\left(E_{\mathrm{g}}\right.$, $\mathrm{eV}$ ) by using energy formula (1), where $h$ is the Planck's constant $\left(6.62607004 \times 10^{-34} \mathrm{~m}^{2} \mathrm{~kg} \mathrm{~s}^{-1}\right), c$ is the speed of light $\left(3.00 \times 10 \mathrm{~m} \mathrm{~s}^{-1}\right)$ and $\lambda$ is the wavelength on the highest peak (Rajkumar \& Suguna 2016).

$$
E g=h c / \lambda
$$

CV was measured by using METROTHM AUTOLAB and NOVA software to study the oxidation and reduction occuring inside the sensitizer. CV measurements involved electrochemical cells comprising glossy carbon as working electrode, $\mathrm{Ag} / \mathrm{AgCl}$ immersed in $3 \mathrm{M} \mathrm{NaCl}$ as reference electrode, platinum as $\mathrm{CE}$, dye sensitizer consisting of $0.1 \mathrm{M}$ lithium perchlorate and $99+\%$ from Acros Organics acting as electrolyte. We calculated HOMO and LUMO from CV by using (2) and (3) and $E_{\mathrm{g}}$ from the PL spectra. $E_{\text {ox }}$ onset at which oxidation occurred was obtained from the CV graph (Leonat et al. 2013).

$$
\begin{aligned}
& E(H O M O)=-e\left[E_{\text {OOx }_{\text {onset }}}+4.4\right] \\
& E(L U M O)=E(H O M O)+E g \\
& \eta=\frac{V o c \times J s c \times x F F}{\operatorname{Pin}}
\end{aligned}
$$

The performances of fully fabricated DSSC were then measured using current-voltage $(I-V)$ characteristics, incident photon current efficiency (IPCE) and electrical impedance spectroscopy (EIS). $I-V$ characteristics were measured using a Keithley 2400 source meter and solar simulator from San-El Electric, with the luminosity of solar light requiring $1000 \mathrm{~W} / \mathrm{m}^{2}$ measured with the Daystar meter. $I-V$ characteristics facilitates the measurement of cell efficiency, which can also be calculated using (4). The formula consists of open circuit voltage $\left(V_{\mathrm{oc}}\right)$, short-circuit current density $\left(J_{\text {sc }}\right)$, fill factor $(\mathrm{FF})$ and Pin $=$ $100 \mathrm{~mW} / \mathrm{cm}^{2}$ (Park et al. 2003). IPCE describes the lightto-electricity conversion efficiency of a photosensitive device. This parameter is dependent on the absorption range of the dye. We used Bentham Photovoltaic Spectral Response PVE300 IPCE. IPCE can also be calculated using (5).

$$
I P C E \%=\frac{I_{S C}}{P} \times \frac{1240}{\lambda} \times 100
$$

EIS measurement was used to study the electrocatalytic activity of the DSSC device by using Autolab Metrothm impedance module. $V_{\mathrm{oc}}$ from I-V measurement is required for measuring EIS. We fit and studied the device impedance using the graph. In fitting analysis, we used the equation $\mathrm{R}(\mathrm{RQ})(\mathrm{RC})$, where the first $\mathrm{R}$ represents the sheet resistance $\left(R_{\mathrm{s}}\right)$, followed by charge transfer resistance $\left(R_{\mathrm{ct}}\right)$ between 
$\mathrm{TiO}_{2} \mathrm{CB}$ and FTO and Q as constant phase element. The last $\mathrm{RC}$ is for the CE side. We focused on $R_{\mathrm{s}}$ and $R_{\mathrm{ct}}$ at the dye and $\mathrm{TiO}_{2}$ location (San Esteban \& Enriquez 2013).

\section{RESULTS AND DISCUSSION}

\section{ABSORPTION SPECTRA}

An efficient sensitizer exhibits a broad wavelength especially within the visible light spectra (400 to 700

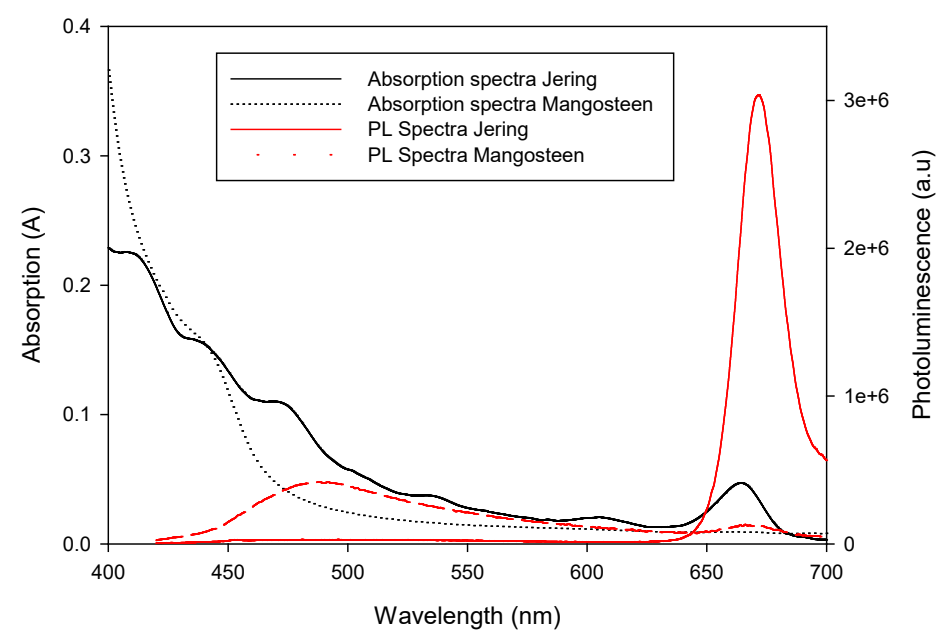

FIGURE 1. Absorption spectra vs photoluminescence spectra for jering and mangosteen dye extracts

$\mathrm{nm})$ to absorb additional light from sunlight radiation. Both jering and mangosteen exhibit different peaks of absorbance (Figure 1), which are due to different colours of pigment extract from each pericarp (Alias \& Yaacob 2016). Both extracts show the highest peak at $400 \mathrm{~nm}$, but jering exhibits a lower peak of 0.05 A compared with that of mangosteen of $0.20 \mathrm{~A}$. Moreover, jering show an additional small peak at $664 \mathrm{~nm}$. Both extracts exhibit blue shifts with decreased performance when reaching high wavelength which were affected by the solvent used and types of pigment inside the extract (Kumar et al. 2019).

\section{PHOTOLUMINESCENCE (PL) SPECTRA}

PL spectra were studied when substances in electronic states were excited by photon, releasing energy as light at different wavelengths. The spectra can be used to calculate energy gap $\left(E_{\mathrm{g}}\right)$ using $(1)$ by obtaining the highest peak wavelength. Both sensitizers also exhibit different spectral behaviour as shown in Figure 1. The highest peaks for the mangosteen and jering sensitizers were at 487 and $671 \mathrm{~nm}$, respectively. Equation (1) was used to obtain $E_{\mathrm{g}}$ for each sensitizer, and $E_{\mathrm{g}}$ values of 2.54

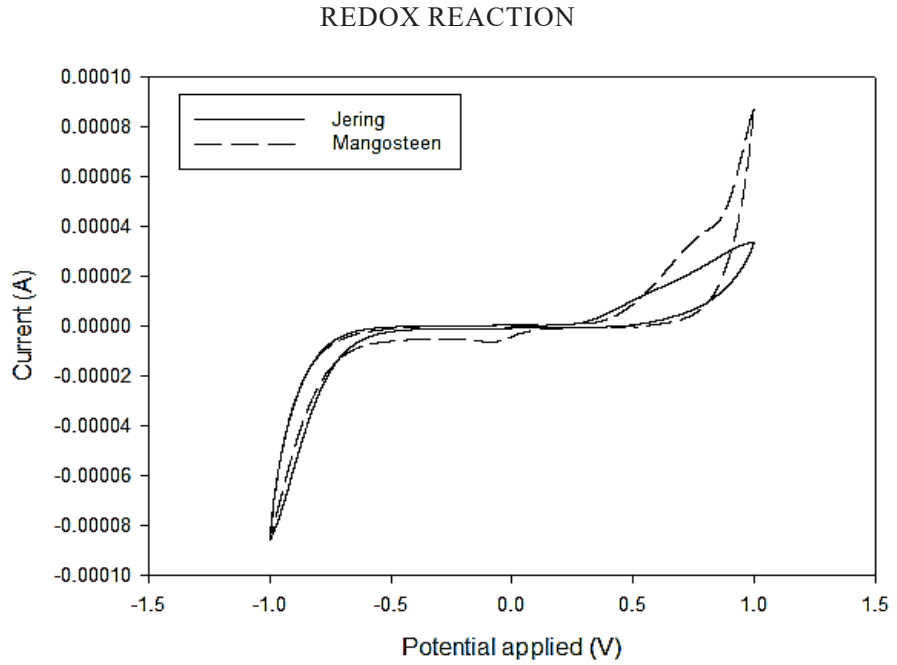

FIGURE 2. Cyclic voltammetry (CV) of jering and mangosteen extractions 
and $1.85 \mathrm{eV}$ were obtained for mangosteen and jering dyes, respectively. Different $E_{\mathrm{g}}$ values for both sensitizers were affected by the colour of the dye extracted from pericarp, that is, dark violet and transparent dark brown for mangosteen and jering, respectively. The small energy gap affected the device, leading to excited electrons returning to ground state levels and consequently affecting electron recombination (Table 1).

TABLE 1. Optical band gap, homo, and lumo calculations

\begin{tabular}{cccccc}
\hline Dye & $\lambda(\mathrm{NM})$ & $E_{\mathrm{G}}(\mathrm{EV})$ & $E_{\text {ox }}{ }^{\text {onset }}(\mathrm{V})$ & HOMO $(\mathrm{eV})$ & LUMO (eV) \\
\hline Jering & 671 & 1.85 & -0.671 & -5.074 & -3.232 \\
Mangosteen & 487 & 2.54 & -0.41 & -4.810 & -2.270 \\
\hline
\end{tabular}

Reduction and oxidation reaction of dye sensitizer can be studied in electrochemical cells in CV. HOMO and LUMO can be calculated by obtaining $E_{\mathrm{ox}}$ onset from the $\mathrm{CV}$ graph (Figure 2) by the inserted value and $E_{\mathrm{g}}$ from PL analysis into (2) and (3). The energy levels were tabulated in Table 2 and illustrated in Figure 3. LUMO should be more positive than the $\mathrm{CB}$ of $\mathrm{TiO}_{2}(-4.0 \mathrm{eV}$ to $-4.3 \mathrm{eV})$, and HOMO should be more negative than the redox $\mathrm{I}_{3}^{-}$$\mathrm{I}^{-}$redox potential $(4.6-5.0 \mathrm{eV})$. Required differences of more than $0.2 \mathrm{eV}$ between the LUMO level of sensitizer and $\mathrm{CB}$ of $\mathrm{TiO}_{2}$ was observed by Ooyama et al. (2013). According to the result that we obtained from the $\mathrm{CV}$ graph, both sensitizers achieved the requirement, with the differences for jering and mangosteen being 1.0 and $1.9 \mathrm{eV}$, respectively. However, HOMO levels for both sensitizers are within the range of electrolyte redox potential by differences of 0.1 and $0.4 \mathrm{eV}$ for jering and mangosteen, respectively. This condition affects DSSC performance by contributing to poor dye regeneration (Safie et al. 2017a).

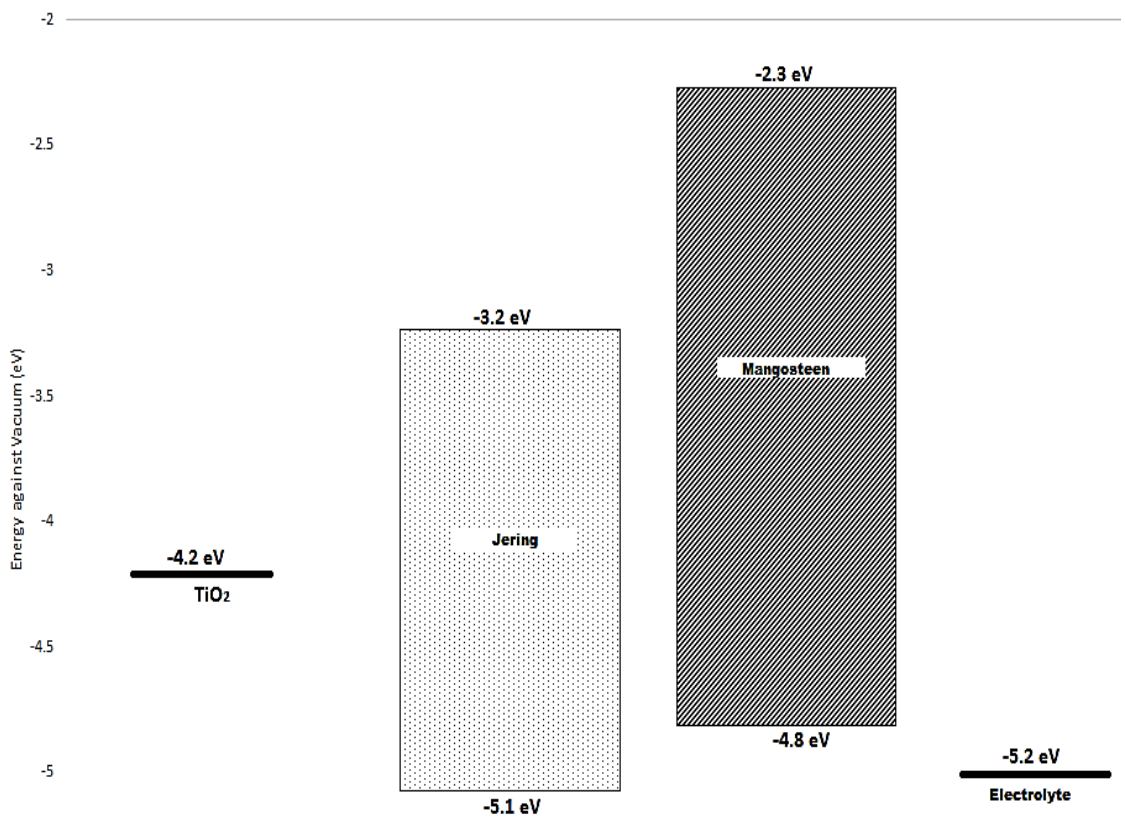

FIGURE 3. Energy level of jering and mangosteen dye sensitizer 


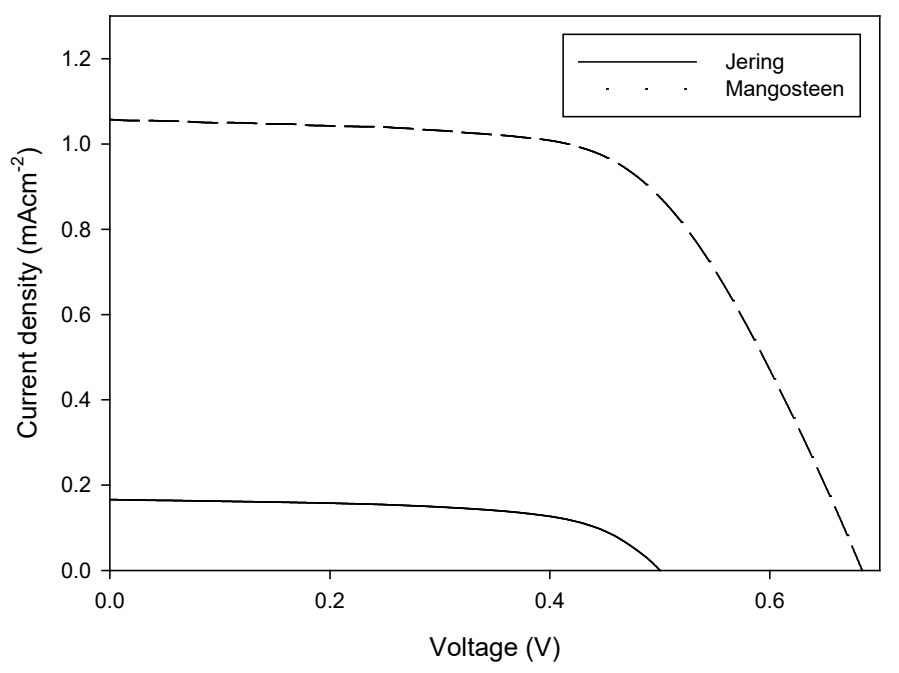

FIGURE 4. I- $V$ characteristics of jering and mangosteen DSSC devices

Jering and mangosteen dye extracts were applied as sensitizer for the DSSC device, and we studied their photovoltaic properties from $I-V$ characteristics in Figure 4 and Table 2. Figure 4 shows that the DSSC device with the mangosteen sensitizer exhibits superior performance to that with the jering sensitizer. This finding is demonstrated in Table 2, where mangosteen exhibits superior efficiencies of 0.38 and $0.074 \%$ to that of the jering sensitizer. Performance can be influenced by current density, which was measured for both DSSCs with jering and mangosteen as 0.20 and $1.03 \mathrm{~mA} / \mathrm{cm}^{2}$, respectively. This result shows that the mangosteen sensitizer presented a large amount of electron transfer from the sensitizer to the $\mathrm{TiO}_{2}$ surface (Jinchu et al. 2016). The low efficiency obtained by jering dye compared to that of mangosteen dye is caused by the HOMO level of jering dye being relatively near to electrolyte redox potential and smaller band gap as seen in Figure 3 (Safie et al. 2017b).

TABLE 2. Photovoltaic parameters of the devices

\begin{tabular}{lcccc}
\hline \multicolumn{1}{c}{ Dye } & $J_{\mathrm{sc}}\left(\mathrm{MA} / \mathrm{CM}^{2}\right)$ & $V_{\mathrm{oc}}(\mathrm{V})$ & $F F(\%)$ & $\eta(\%)$ \\
\hline Jering & 0.2 & 0.51 & 72.48 & 0.07 \\
Mangosteen & 1.03 & 0.64 & 57.32 & 0.38 \\
\hline
\end{tabular}

IPCE

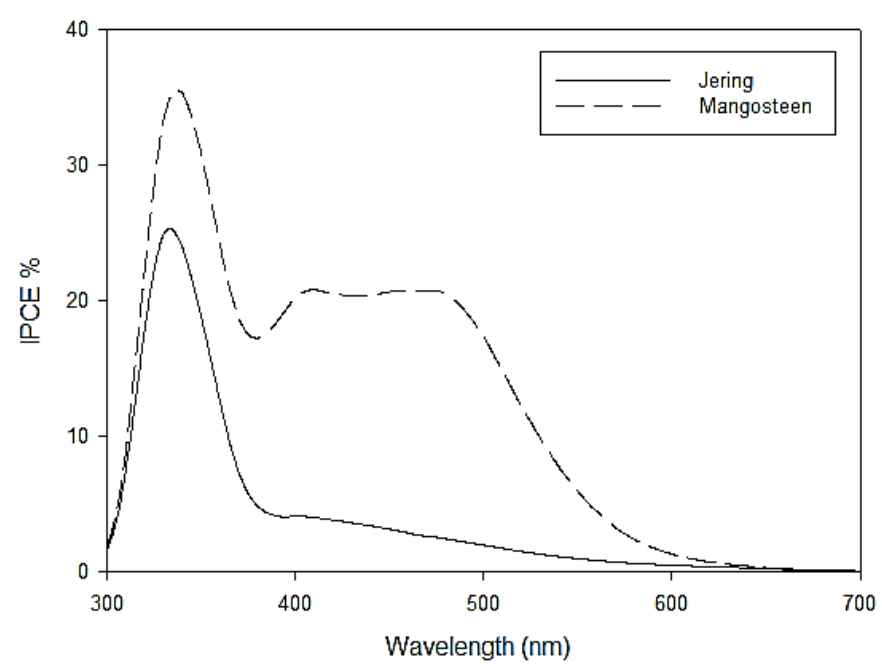

FIGURE 5. IPCE spectra for jering and mangosteen as DSSC sensitizer 
Photon conversions to electron efficiency can be studied using IPCE from the spectral range of 300 to 700 $\mathrm{nm}$. The IPCE measurements can be seen in Figure 5, which shows the highest peak for the DSSC devices with jering and mangosteen at $337 \mathrm{~nm}$ and efficiencies of 25.31 and $35.43 \%$, respectively. These peaks represent $\mathrm{TiO}_{2}$, to which the attached dye helps improve the efficiency of photon conversions (Godibo et al. 2014). The action spectra occurring from 400 to $700 \mathrm{~nm}$ represent the dye itself. The mangosteen sensitizer exhibited constant photon conversion from $406 \mathrm{~nm}$ to $480 \mathrm{~nm}$ and then displayed a blue shift that is characteristic of the absorption spectra in Figure 1. The DSSC device with jering dye as sensitizer did not show significant behaviour under visible light range. The dye colour improved device performance until the wavelength range light entered the devices.

IMPEDANCE ANALYSIS

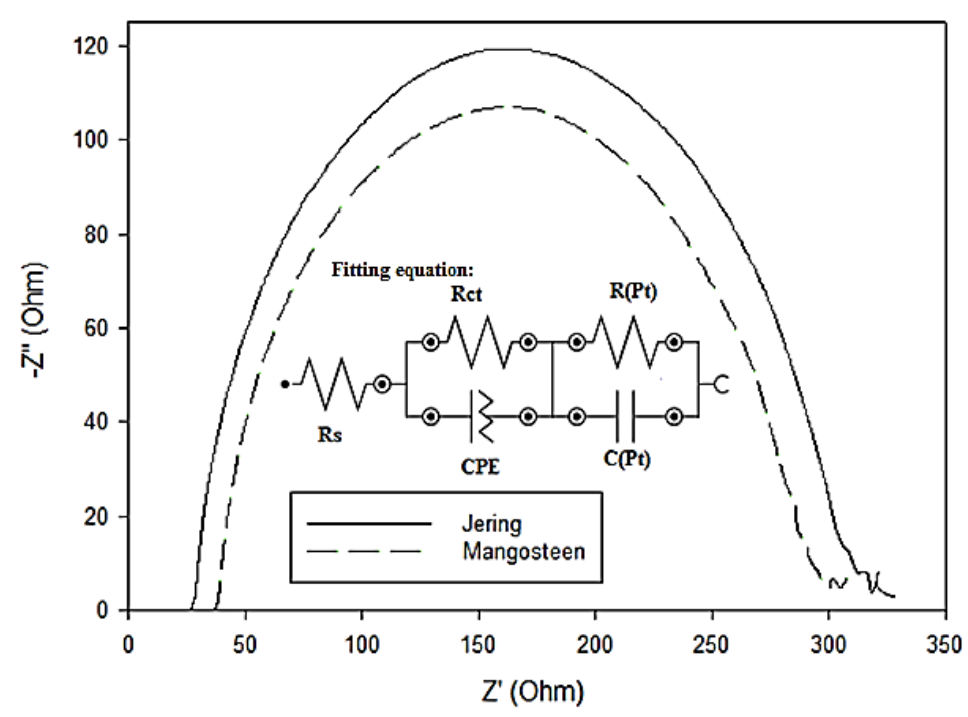

FIGURE 6. Nyquist curve and fitting equation for jering and mangosteen sensitizers for DSSC

Electrocatalytic reaction within DSSC device can be studied with EIS measurement, where impedance can be measured using a suitable fitting equation. The fitting equation used in this study was $\mathrm{R}(\mathrm{RQ})(\mathrm{RC})$ as shown in Figure 6, and the equation was simulated in NOVA software and fit in a circle with the EIS graph. From the fit and simulation, we were able to obtain DSSC $R_{\mathrm{S}}$ and $\mathrm{R}_{\mathrm{ct}}$ as tabulated in Table 3 . The DSSC device with mangosteen as sensitizer has smaller sheet resistance $R_{\mathrm{s}}$ at $37.75 \Omega$ compared with the DSSC device with jering at 490.70 $\Omega$. This finding showed that the mangosteen sensitizer exhibits more efficient electron transfer within the device compared with the jering dye sensitizer. This result was due to the increase in dark colour of the dye photon-electron conversion, therefore increasing electron transfer and decreasing resistance (Zhou et al. 2011).

TABLE 3. Current - voltage characteristics

\begin{tabular}{cccc}
\hline Dye & $\chi^{2}$ & $R_{\mathrm{s}}(\Omega)$ & $R_{\mathrm{ct}}(\Omega)$ \\
\hline Jering & 0.02 & 490.70 & 282.68 \\
Mangosteen & 0.02 & 37.75 & 256.77 \\
\hline
\end{tabular}




\section{CONCLUSION}

Garcinia mangostana and Archidendron pauciflorum can be easily found in South Asia, where the fruits are used for their nutrients as healthy or daily snacks. In this study, we used fruit pericarps, which was extracted with methanol solvents to obtain colour pigments and used as DSSC sensitizer. Each extract contains different colours pigment, affecting the UV-Vis spectra, PL and Eg. Mangosteen sensitizer has wider Eg of $2.54 \mathrm{eV}$ compared with jering sensitizer of $1.85 \mathrm{eV}$. Mangosteen sensitizer also affects the HOMO and LUMO levels. Mangosteen sensitizer has significant electrochemical properties compared with jering sensitizer, therefore, influence the photovoltaic properties when the extracts were applied as DSSC sensitizer. When the photoanode layer was immersed in both sensitizers, namely, jering and mangosteen, mangosteen-DSSC-based sensitizer has darker colour than the jering-DSSC-based sensitizer. Therefore, mangosteen dye as sensitizer has an efficiency of $0.38 \%$, and jering dye as sensitizer has $0.07 \%$. Both sensitizers have a low efficiency compared with the artificial sensitizer. From this study, we were able to confirm that natural products especially mangosteen and jering have the capability to be used as DSSC sensitizer, but their performance can be improved in future works by added suitable catalyst as co-adsorbance or dye purification.

\section{ACKNOWLEDGEMENTS}

Solar Energy Research Institute (SERI) UKM, Dana Impak Perdana (DIP-2019-025), Centre for Research and Instrumentation Management UKM (CRIM UKM), Universiti Kebangsaan Malaysia (UKM).

\section{REFERENCES}

Al-Alwani, M.A., Mohamad, A.B., Kadhum, A.A.H., Ludin, N.A., Safie, N.E., Razali, M.Z., Ismail, M. \& Sopian, K. 2017. Natural dye extracted from Pandannus amaryllifolius leaves as sensitizer in fabrication of dye-sensitized solar cells. International Journal of Electrochemical Science 12(1): 747-761.

Alias, N.N. \& Yaacob, K.A. 2016. Natural dye sensitizer in dye sensitized solar cell. Sains Malaysiana 45(8): 1227-1234.

Attanayake, C.I.F., de Silva, C., Premachandra, B.A.J.K., De Alwis, A.A.P. \& Senadheera, G.K.R. 2013. Dye-sensitized solar cells: using over 100 natural dyes as sensitizers. 2013 AIChE Annual Meeting. pp. 1-16.

Bunawan, H., Dusik, L., Bunawan, S.N. \& Amin, N.M. 2013. Botany, traditional uses, phytochemistry and pharmacology of Archidendron jiringa: A review. Global Journal of Pharmacology 7(4): 474-478.

Godibo, D.J., Anshebo, S.T. \& Anshebo, T.Y. 2015. Dye sensitized solar cells using natural pigments from five plants and quasi-solid state electrolyte. Journal of the Brazilian Chemical Society 26(1): 92-101.
Jinchu, I., Sreekala, C.O., Sreelatha, K.S. \& Mohan, R.E. 2016. Photovoltaic parameters of DSSCs using natural dyes with $\mathrm{TiO}_{2}$ nanopowder and nanofiber as photoanodes: A comparative study. 2016 International Conference on Electrical, Electronics, and Optimization Techniques (ICEEOT) 4154-4157.

Jung, H.A., Su, B.N., Keller, W.J., Mehta, R.G. \& Kinghorn, A.D. 2006. Antioxidant xanthones from the pericarp of Garcinia mangostana (Mangosteen). Journal of Agricultural and Food Chemistry 54(6): 2077-2082.

Kumar, N.S., Ibrahim, A.A., Dhar, A. \& Vekariya, R.L. 2019. Optoelectrical characterization of different fabricated donor substituted benzothiazole based sensitizers for efficient DSSCs. Journal of Photochemistry and Photobiology A: Chemistry 372: 35-41.

Kushwaha, R., Srivastava, P. \& Bahadur, L. 2013. Natural pigments from plants used as sensitizers for $\mathrm{TiO}_{2}$ based dye-sensitized solar cells. Journal of Energy 2013: Article ID. 654953.

Leonat, L., Sbarcea, G. \& Branzoi, I.V. 2013. Cyclic voltammetry for energy levels estimation of organic materials. $U P B$ Scientific Bulletin, Series B: Chemistry and Materials Science 75(3): 111-118.

Maiaugree, W., Lowpa, S., Towannang, M., Rutphonsan, P., Tangtrakarn, A., Pimanpang, S., Maiaugree, P., Ratchapolthavisin, N., Sang-Aroon, W., Jarernboon, W. \& Amornkitbamrung, V. 2015. A dye sensitized solar cell using natural counter electrode and natural dye derived from mangosteen peel waste. Scientific Reports 5(1): 15230.

Mariey, L., Signolle, J.P., Amiel, C. \& Travert, J. 2001. Discrimination, classification, identification of microorganisms using FTIR spectroscopy and chemometrics. Vibrational Spectroscopy 26(2): 151-159.

O’regan, B. \& Grätzel, M. 1991. A low-cost, high-efficiency solar cell based on dye-sensitized colloidal $\mathrm{TiO}_{2}$ films. Nature 353(6346): 737-740.

Ooyama, Y., Hagiwara, Y., Mizumo, T., Harima, Y. \& Ohshita, J. 2013. Photovoltaic performance of dye-sensitized solar cells based on D- $\pi-$ A type BODIPY dye with two pyridyl groups. New Journal of Chemistry 37(8): 2479-2485.

Park, N.G., Kang, M.G., Ryu, K.S., Kim, K.M. \& Chang, S.H. 2004. Photovoltaic characteristics of dye-sensitized surface-modified nanocrystalline $\mathrm{SnO}_{2}$ solar cells. Journal of Photochemistry and Photobiology A: Chemistry 161(23): 105-110.

Rajkumar, S. \& Suguna, K. 2016. Analysis of natural sensitizers to enhance the efficiency in dye sensitized solar cell. International Journal of Engineering Research and Applications 6(5): 41-46.

Safie, N.E., Hamid, N.H., Sepeai, S., Teridi, M.A.M., Ibrahim, M.A., Sopian, K. \& Arakawa, H. 2017a. Energy levels of natural sensitizers extracted from rengas (Gluta spp.) and mengkulang (Heritiera elata) wood for dye-sensitized solar cells. Materials for Renewable and Sustainable Energy 6(2): 5 .

Safie, N.E., Ludin, N.A., Hamid, N.H., Tahir, P.M., Teridi, M.A.M., Sepeai, S., Ibrahim, M.A. \& Sopian, K. 2017 b. Electron transport studies of dye-sensitized solar cells based on natural sensitizer extracted from rengas (Gluta spp.) and mengkulang (Heritiera elata) wood. Bioresources 12(4): 9227-9243. 
San Esteban, A.C.M. \& Enriquez, E.P. 2013. Grapheneanthocyanin mixture as photosensitizer for dye-sensitized solar cell. Solar Energy 98: 392-399.

Sathyajothi, S., Jayavel, R. \& Dhanemozhi, A.C. 2017. The fabrication of natural dye sensitized solar cell (DSSC) based on $\mathrm{TiO}_{2}$ using henna and beetroot dye extracts. Materials Today: Proceedings 4(2): 668-676.

Shahid, M. \& Mohammad, F. 2013. Recent advancements in natural dye applications: A review. Journal of Cleaner Production 53: 310-331.

Tontapha, S., Sang-Aroon, W., Kanokmedhakul, S., Promgool, T. \& Amornkitbamrung, V. 2017. Effects of dye-adsorption solvents, acidification and dye combination on efficiency of DSSCs sensitized by $\alpha$-mangostin and anthocyanin from mangosteen pericarp. Journal of Materials Science: Materials in Electronics 28(10): 7454-7467.

Ye, M., Wen, X., Wang, M., Iocozzia, J., Zhang, N., Lin, C. \& Lin, Z. 2015. Recent advances in dye-sensitized solar cells: From photoanodes, sensitizers and electrolytes to counter electrodes. Materials Today 18(3): 155-162.

Zhou, H., Wu, L., Gao, Y. \& Ma, T. 2011. Dye-sensitized solar cells using 20 natural dyes as sensitizers. Journal of Photochemistry and Photobiology A: Chemistry 219(2-3): 188-194.

Zulkifili, A.N.B., Kento, T., Daiki, M. \& Fujiki, A. 2015. The basic research on the dye-sensitized solar cells (DSSC). Journal of Clean Energy Technologies 3(5): 382-387.

Mashasriyah Ismail, Norasikin Ahmad Ludin*, Suhaila Sepeai, Mohd Adib Ibrahim \& Mohd Asri Mat Teridi

Solar Energy Research Institute (SERI)

Universiti Kebangsaan Malaysia

43600 UKM Bangi, Selangor Darul Ehsan

Malaysia
Norul Hisham Hamid

Biocomposite Unit

Institute of Tropical Forestry and Forest Products

Universiti Putra Malaysia

43400 UPM Serdang, Selangor Darul Ehsan

Malaysia

Mahmoud A.M. Al-Alwani

Department of Biology

College of Education for Pure Sciences/Ibn Al-Haitham

University of Baghdad

Baghdad, Iraq

Norani Muti Muhamed

Centre of Innovative Nanostructures \& Nanodevices (COINN)

Universiti Teknologi Petronas (UTP)

32610 Seri Iskandar, Perak Darul Ridzuan

Malaysia

Unit of Fundamental Studies

Faculty of Engineering and Environment Built

Universiti Kebangsaan Malaysia

43600 UKM Bangi, Selangor Darul Ehsan

Malaysia

*Corresponding author; email: sheekeen@ukm.edu.my

Received: 12 August 2020

Accepted: 27 August 2020 